\title{
Subsurface Seawater Intrusion, an Additional Factor Influencing the Limnological History of the Dead Sea Basin
}

\author{
Uri Kafri (Corresponding author) \\ Geological Survey of Israel \\ 30 Malchei Israel St. Jerusalem, 95501, Israel \\ Tel: 972-253-14288Ｅ-mail: uri.kafri@gsi.gov.il
}

Received: August 30, 2016 Accepted: September 23, 2016

doi:10.5296/emsd.v5i2.10130ＵRL: http://dx.doi.org/10.5296/emsd.v5i2.10130

\begin{abstract}
A deep core hole, drilled in the middle of the Dead Sea penetrated the Pleistocene- Holocene section, revealed an alternating sequence of fresh water and evaporitic (gypsum, halite) deposits. The vertical facies variations were interpreted as related mainly to lake level changes during this period. The present study, however, proposes an additional factor that influenced these changes, namely subsurface seawater intrusion from the Mediterranean Sea to the endorheic Dead Sea Basin. This proposed process is controlled by the elevation and head difference between both base levels at a given time, because the Mediterranean Sea level also fluctuated during the discussed period. We find that in times of smaller head differences, and assumed lower seawater intrusion, a gypsum facies prevailed in the Dead Sea Basin. In times of greater head differences and assumed more abundant seawater intrusion a halite facies prevailed because of greater sodium chloride input into the Dead Sea.
\end{abstract}

Keywords: Dead Sea Basin. Seawater Intrusion. Evaporites

\section{Introduction}

\subsection{The Dead Sea Basin}

The history of the Dead Sea Basin ("DSB") (Fig 1) and its occupied paleo- lakes since the Neogene was discussed in detail in several studies (Horowitz, 2001; Stein, 2001), some of which will be referred to in the present study. A rather short description follows:

The DSB was formed as a pull-apart basin along the Dead Sea Transform during the Neogene (Garfunkel, 1981), forming an endorheic continental base level. Later, during the Pliocene, 
the Mediterranean Sea invaded the basin through internal morpho-tectonic valleys of northern Israel, forming the Sedom Lagoon as an inland evaporitic basin (Zak, 1967). Subsequently, the Sedom Lagoon was disconnected from the open sea (Kafri and Ecker, 1964; Zak, 1967; Stein, 2001; Torfstein et al., 2009).

Following the severance of the DSB from the Mediterranean, three consecutive major lacustrine and hypersaline water bodies (Katz et al., 1977; Torfstein et al., 2009) occupied the DSB throughout Pleistocene-Holocene time: Lake Amora (including Lake Samra), Lake Lisan, and the present day DSB. The water levels of these lakes fluctuated because of climate changes and tectonic subsidence of the basin (Stein, 2001; Bartov, et al., 2006; Waldmann, et al., 2009).

Lake Amora existed between 740 and $70 \mathrm{ka}$ whereas its inclusive Lake Samra existed between 135 and $70 \mathrm{ka}$ at water levels between 320 and $380 \mathrm{~m}$ below Mediterranean Sea level (hereafter bsl). Lake Lisan existed between 70 and $15 \mathrm{ka}$ at Mediterranean water levels that fluctuated between 330 and $150 \mathrm{~m}$ bsl. The DS levels during the Holocene were about $400 \mathrm{~m}$ bsl (Stein, 2001; Torfstein, et al., 2009).

Most of the relevant studies show the linkage between the lake levels and the sedimentary facies deposited within them. In general, high lake levels, mostly during glacial periods result in an aragonite-detritus sedimentary facies. Low lakes levels, during interglacial periods, result in halite deposition. Gypsum deposition is related to lakes level declines (i.e., Bartov, et al., 2003; Torfstein, et al., 2013; Neugebauer, et al., 2014).

The present study proposes seawater intrusion (hereafter SSI) from the Mediterranean Sea to the DSB, which might influence the sedimentary facies composition.

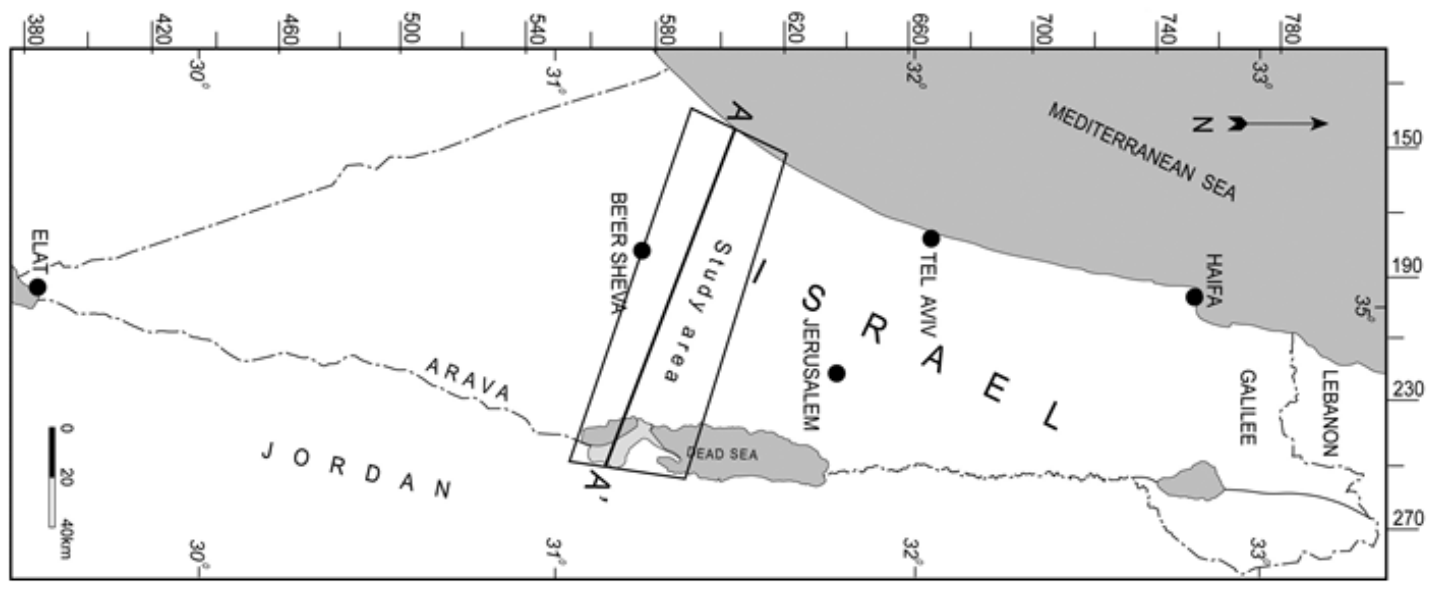

Figure 1. Location map of the study area

\subsection{Subsurface Seawater Intrusion (SSI) Into the DSB}

The DSB is a continental endorheic (terminal) base level only tens of kilometers from the Mediterranean Sea Presently it is up to $430 \mathrm{~m}$ below the Mediterranean Sea level. Based on hydraulic continuity between both base levels we suggested that current subsurface seawater intrusion ("SSI") from the higher Mediterranean to the lower DSB base level occurs thereby 


\section{Macrothink}

contributing to the salinity of the DSB. Kafri and Arad (1979) reported this in the northern part of the DSB. It was also discussed by Kafri et al. (2007) and Kafri and Yechieli (2010). The same configuration of continental endorheic base levels below sea level and not far from the sea, are known in other places in the world and there also they are claimed to be caused by SSI. (Kafri, 1984; Kafri and Yechieli, 2010; Kafri et al., 2013).

Recently, Kafri et al. (2014) studied and described the same phenomenon of SSI to the DS in southern Israel through the Be'er Sheva valley, based on geo-electric measurements, geochemical parameters and hydrological modeling. The hydrogeological setup, along the Be'er Sheva Valley is shown on a cross section along it that connects both base levels (Fig. 2). The study area of the Be'er Sheva Valley extends on both sides of the regional groundwater divide between both base levels. The sequence above the Pre-Cambrian basement includes Paleozoic to Quaternary sedimentary formations, as detailed in Figure 2.

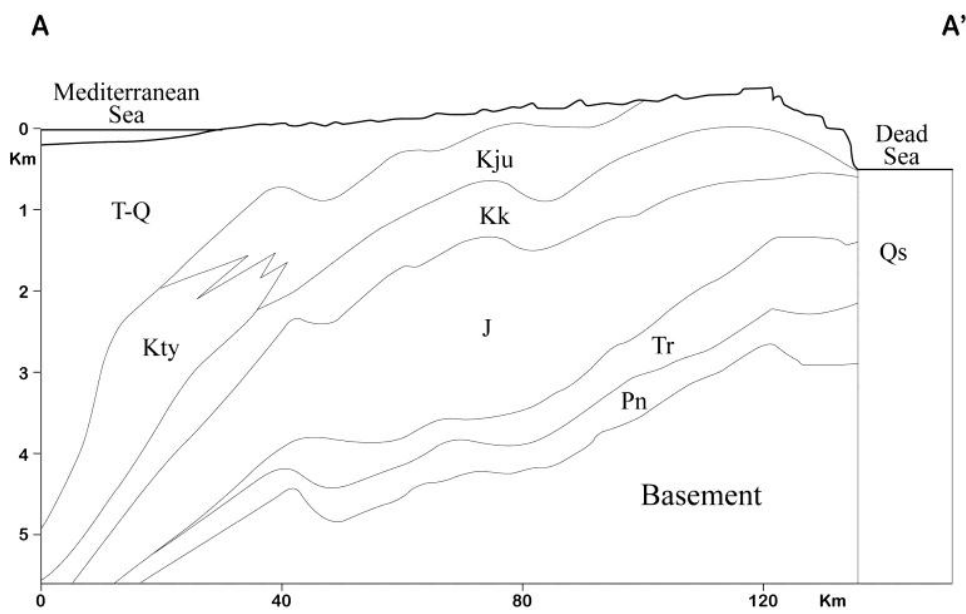

Figure 2. Geological cross section along the Be'er Sheva Valley (modified after Stanislavsky and Gvirtzman 1999): Pn-Paleozoic; Tr-Triassic; J- Jurassic;Kk- Lower Cretaceous; Kju- Upper Cretaceous; Kty-Cretaceous Talme Yaffe Formation; T-Q- Tertiary to Quaternary; Qs- Quaternary Dead Sea Graben fill

Those formations which consist partly of carbonates and sandstones are hydraulically conducive to groundwater flow. The hydraulic parameters of the discussed sequence and the groundwater regime in this area were described by Stanislavsky and Gvirtzman (1999) and Grabe et al. (2013). The flow directions in the study area as obtained by the particle tracking procedure of the FeFlow model (Diersch, 2005) are shown on Figure 3. 


\section{Macrothink}

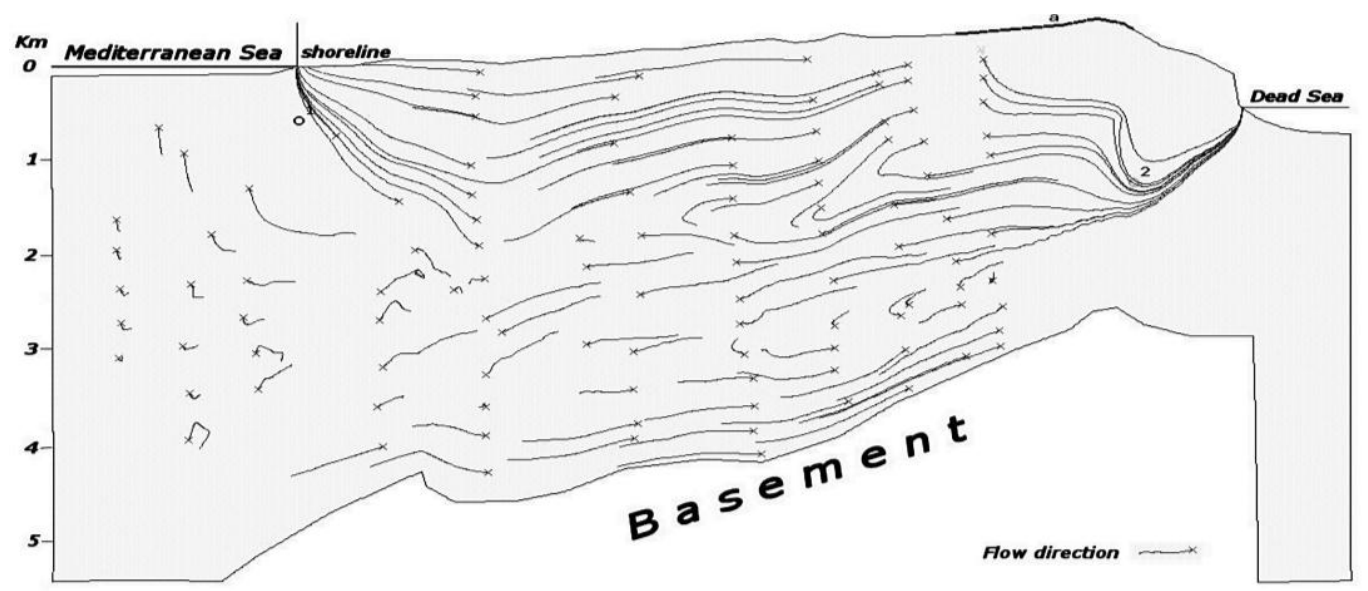

Figure 3. Flow directions as obtained by particle tracking procedure of the FeFlow model (Kafri et al 2014)

The hydrogeological configuration of SSI from the Mediterranean Sea to the DS and the density driven brine flow (hereafter DDBF) towards the west is shown schematically on Figure 4.

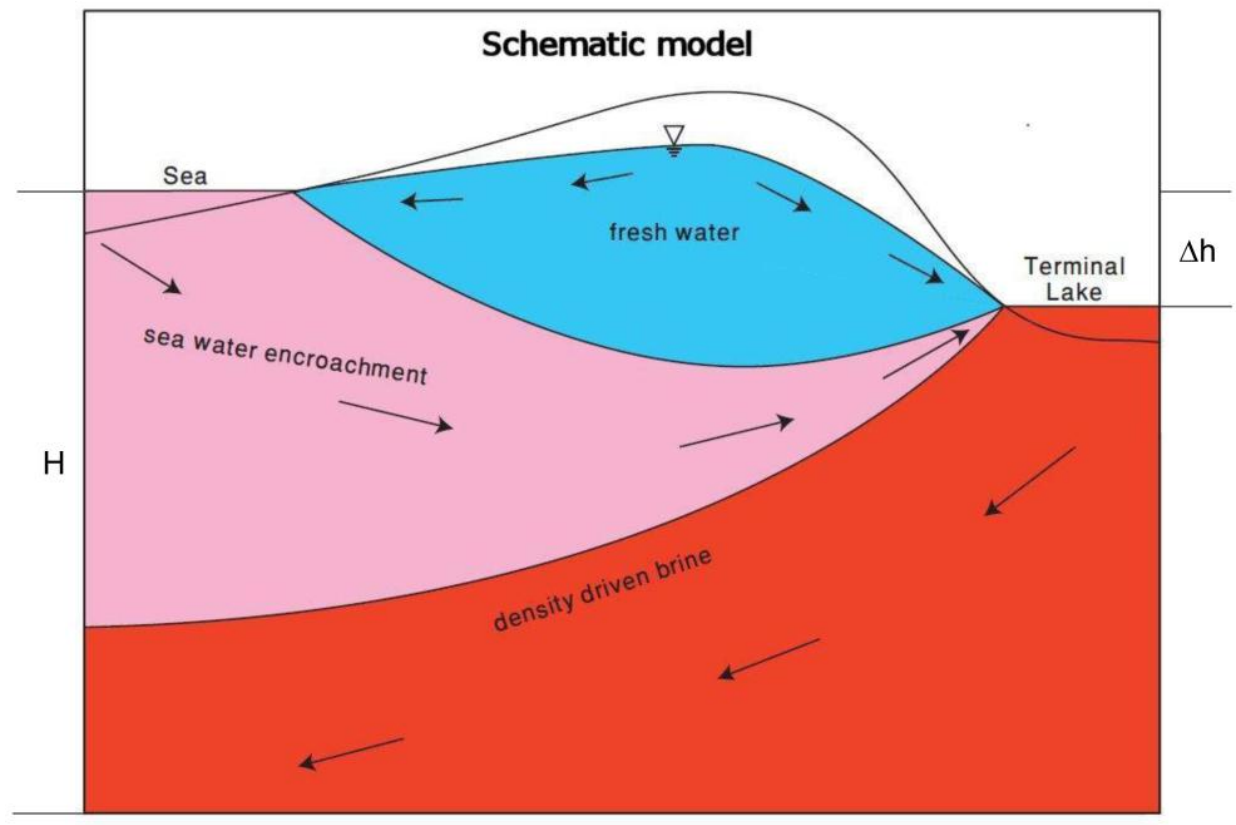

Figure 4. Schematic flow model between the Mediterranean Sea and the DSB. H= Depth of the base of the flow; $\Delta \mathrm{h}=$ Elevation difference between the Mediterranean and the DSB levels

\section{Methods}

The working hypothesis of the present study is based on the findings that the Mediterranean and the DSB base levels are hydrologically connected and thus enabling SSI, from the former to the latter, due to the head difference between them (Kafri et al., 2014). Since the elevations of both base levels changed during the Pleistocene -Holocene, the elevation difference for each time period was calculated. In addition, the head differences were also calculated, taking 
into account the densities of the different water bodies, contained in the Mediterranean and the DS during those time periods. The obtained head differences were correlated with the different sedimentary facies that prevailed at those time periods.

\section{Results and Discussion}

\subsection{Dead Sea Deep Drilling Core}

A $455 \mathrm{~m}$ long continuous core was retrieved from a deep core hole drilled in 2010-2011 in the middle of the DS at a water depth of $300 \mathrm{~m}$. The analysis of the core described the different sedimentary facies of the penetrated Pleistocene to Holocene sediments. (Neugebauer,et al., 2014; Torfstein, et al., 2015b). Their description and interpretation, in general describes the different facies:

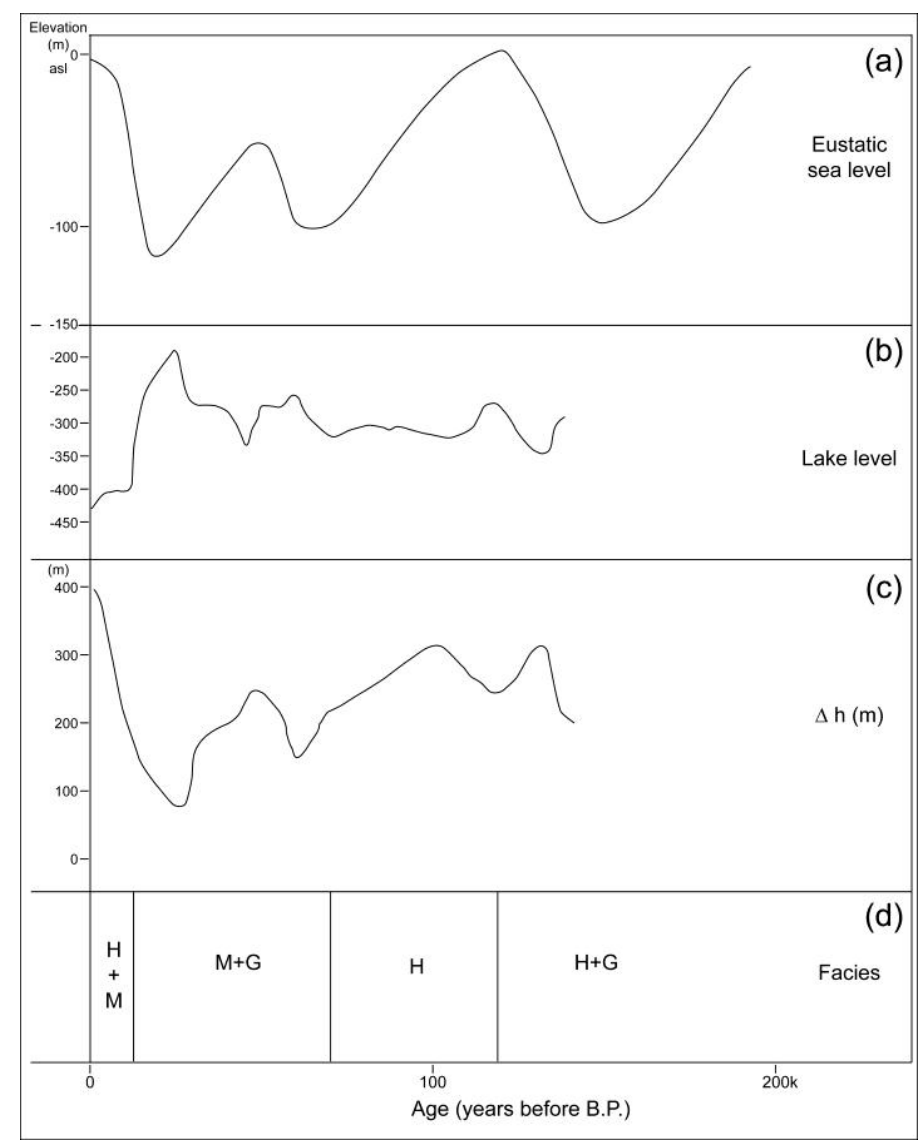

Figure 5. (a) Simplified Pleistocene-Holocene global and Mediterranean Sea levels (after Waldmann et al. 2009). (b) Pleistocene- Holocene DSB lake levels (after Waldmann et al. 2009). (c) Pleistocene- Holocene elevation difference ( $\Delta \mathrm{h})$ between the Mediterranean and the DSB levels. (d) Depositional facies changes along the DS deep drilling core. $M=$ marl facies: $\mathrm{G}=$ gypsum facies; $\mathrm{H}=$ halite facies

(a) A marl facies, which comprising mainly aragonite and silty detritus, that deposited during high lake levels in the glacial stages (M on Fig. 5 d),

(b) A halite facies, deposited during low lake levels in the interglacial stages (H on Fig. 5 d), 
(c) A gypsum facies associated with episodes of declining lake levels (G on Fig. 5 d),

(d) A coarse clastic detritus facies.

The reported findings resulted in a debate as to the interpretation of the environment of deposition of part of the sequence. A $40 \mathrm{~m}$ halite-dominant core was dated to 110-120 ka at a level of $235 \mathrm{~m}$ below the DS bottom ("blb"). Torfstein et al. (2015a) related this to a sudden and rapid drawdown of the DS level. Katz and Starinsky (2015) commented by rejecting this interpretation, based on geochemical parameters. They also claimed that the proposed water depth was not sufficient enough to deposit a $40 \mathrm{~m}$ thick halite sequence. It should be mentioned, in this regard, that the present day depth of $235 \mathrm{~m}$ below the lake floor is a result of post depositional tectonic subsidence in the center of the basin, at rates of over $1 \mathrm{~mm} / \mathrm{y}$ that were previously described (Bartov et al., 2006). Katz and Starinsky (2015) also proposed, to overcome the above mentioned salinity deficiency, an external import of salts derived from leaching of salt bodies in the catchment area, which was accepted in the response of Torfstein, et al (2015b). Another additional external salt contribution to the basin is proposed in the present study (see below).

The present study deals with the possible effect of SSI on the sedimentary facies of the DSB during the Pleistocene-Holocene. During this period the hydraulic system between the Mediterranean Sea and the DSB did not change. The active aquifers and their hydraulic properties are assumed constant. Regarding the water input to the basin, Enzel, et al. (2003) proposed a relationship between the DS levels and rainfall assumingly that most of the input is through surface runoff. Most of the water input to the basin is groundwater that was naturally recharged to the system following an evapotranspiration process and subsequently fed the basin through subsurface flow and big springs. In this case it is possible that, even in cooler (glacial) periods when rainfall was less (Bar- Matthews and Ayalon, 2003), the net recharge to the aquifers did not differ considerably from that of the more humid and warm periods, due to reduced evapotranspiration as suggested by Yechieli, et al. (2009). Significant changes in the system are, thus, not only the DSB level variations but also those of the Mediterranean base level (Fig. 5 a, b). An attempt is made herein to show that the sedimentary facies is controlled not only by the DSB levels, as advocated but also by the differences between both base levels at each period (Fig. 5c) and the resultant SSI.

In Figs. 5c \& d, the gypsum facies (G) prevails in periods $\sim 75-55$ and $\sim 20-14$ ka BP (Neugebauer, et al, 2014) when the elevation difference between both base levels (" $\Delta \mathrm{h}$ ") was about $200 \mathrm{~m}$. The halite facies $(\mathrm{H})$, however, prevailed between $\sim 120-75 \mathrm{ka} \mathrm{BP}$ and from the Holocene to the present (Neugebauer,, et al., 2014; Torfstein, et al., 2015). During this period, $\Delta \mathrm{h}$ exceeded $300 \mathrm{~m}$ and even attains a value of over $400 \mathrm{~m}$ at present. A time lag exists for the change of $\Delta \mathrm{h}$ and the resultant change of facies. It is, proposed that the evaporative facies is also controlled by the rate of SSI which is affected by the $\Delta \mathrm{h}$ between both base levels as described below.

\section{$3.2 \triangle P$ For SSI and DDBF as a Function Of $\triangle H$ Between Both Base Levels}

Assuming a hydraulic subsurface continuum between the Mediterranean and the DS base levels and a resultant SSI, then the rate of the latter is controlled by the head difference $(\Delta \mathrm{P})$ 


\section{Macrothink}

between both. According to Bernouli's Equation this depends on the density of seawater and the elevation difference between the base levels and is given as:

$$
\Delta \mathrm{P}_{(\mathrm{ssi})}=\dot{\rho}_{(\mathrm{sw})} \cdot \mathrm{g} \cdot \Delta \mathrm{h}
$$

Where $\Delta \mathrm{P}_{\text {(ssi) }}$ is the potential head difference, $\dot{\rho}$ (sw) is the seawater density and $\Delta \mathrm{h}$ is the elevation difference between both base levels. In both cases the atmospheric head acting on the base levels is atmospheric which will be slightly different depending on temperature and humidity. This difference is likely small. The rate of the deeper DDBF is also controlled by the pressure difference between both base levels which depends also on their different water densities as follows:

$$
\Delta \mathrm{P}_{(\mathrm{ddbf})}=\left(\dot{\rho}{ }_{(\mathrm{dsb})}-\dot{\rho}{ }_{(\mathrm{sw})}\right) \cdot \mathrm{g} \cdot \mathrm{H}-\dot{\rho}{ }_{(\mathrm{dsb})} \cdot \mathrm{g} \cdot \Delta \mathrm{h}
$$

Where $\dot{\rho}_{(\mathrm{dsb})}$ is the DSB density and H is the elevation of the base of the flow.

The $\triangle \mathrm{P}$ for $\mathrm{SSI}$ and DDBF was calculated for the two significant cases of a lake depositing gypsum ( $\mathrm{G}$ facies) and one that deposits halite ( $\mathrm{H}$ facies). A depth of $5000 \mathrm{~m}$ was set for the base of the flow system. In the case of the $\mathrm{G}$ facies $\Delta \mathrm{h}$ is around $200 \mathrm{~m}$, the seawater density is $1.025 \mathrm{gr} / \mathrm{cm}^{3}$ and the density of the brine in the DSB that deposits gypsum is around $1.1 \mathrm{gr} / \mathrm{cm}^{3}$ (Starinsky, 1974).In the case of the $\mathrm{H}$ facies, $\Delta \mathrm{h}$ is about $400 \mathrm{~m}$, the Mediterranean seawater density is as above, and that of the brine in the DSB that deposits halite is $1.24 \mathrm{gr} / \mathrm{cm}^{3}$ (Starinsky, 1974).

The calculated results of $\Delta \mathrm{P}$ for SSI and DDBF for both facies are exhibited in Fig 6 . It is clearly noticed that for the SSI component at a $\Delta \mathrm{h}$ of $200 \mathrm{~m}$, the obtained $\Delta \mathrm{P}$ is around 1500 $\mathrm{kPa}$, whereas at a $\Delta \mathrm{h}$ of $400 \mathrm{~m}$ it attains a value close to $6000 \mathrm{kPa}$, and thus as a result a considerably higher rate of SSI flow. Considering the DDBF component, it is noticed that the $\Delta \mathrm{P}$ at the $\Delta \mathrm{h}$ of $200 \mathrm{~m}$ is around $2000 \mathrm{kPa}$, whereas at the $\Delta \mathrm{h}$ of $400 \mathrm{~m}$ it is as high as around $4000 \mathrm{kPa}$.

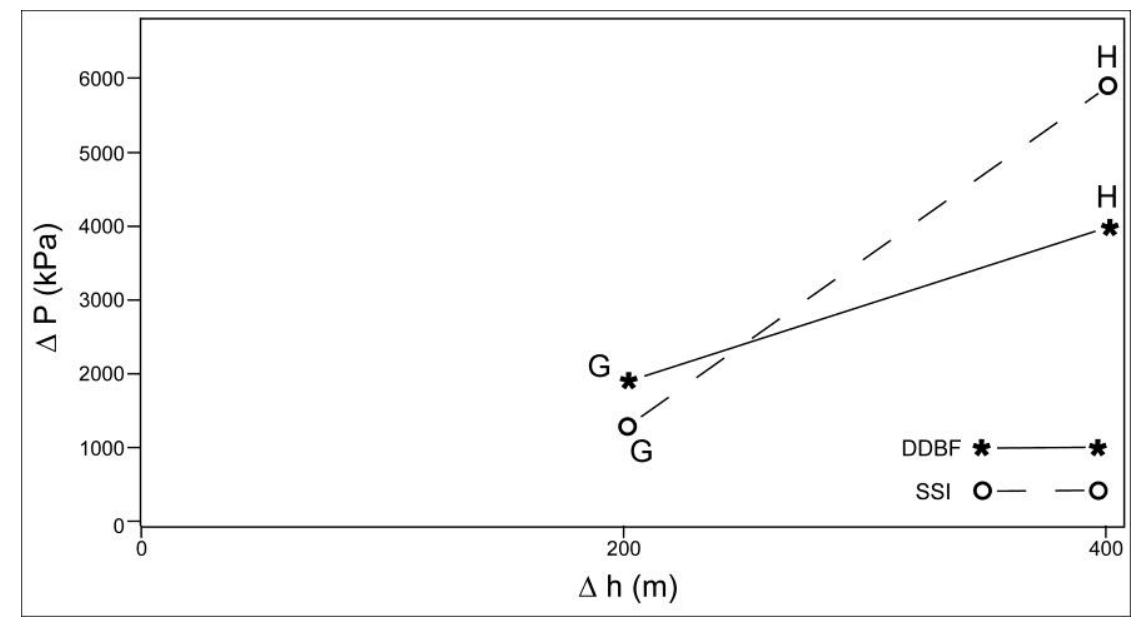

Figure 6. Pressure (head) differences $(\triangle \mathrm{P})$ between the Mediterranean and the DSB base levels during the processes of SSI and DDBF for the scenarios of $\Delta \mathrm{h}=200 \mathrm{~m}$ ( $\mathrm{G}$ facies) and 400m ( $\mathrm{H}$ facies) 


\section{Conclusions}

The terminal endorheic DSB exhibits during the Pleistocene-Holocene variations in the facies of its deposited evaporites, as encountered along the DSDP core recovered from the center of the DS. Those were related, in general, to lake level variations. Others have advocated and agreed that in the case of a $40 \mathrm{~m}$ thick halite unit its thickness is "several times larger than that which could have been provided by a brine column in composition to that of the DS". That is, the source of salinity was partly external, being provided by leaching of salt bodies in the catchment area (Katz and Starinsky, 2015; Torfstein et al., 2015b).

The present study proposes an alternative source of salinization of the DSB, namely subsurface seawater intrusion from the Mediterranean Sea to the DSB (SSI). During the period under consideration both base levels fluctuated but maintained an elevation $(\Delta \mathrm{h})$ and a resultant head $(\Delta \mathrm{P})$ difference between them. At times a lower $\Delta \mathrm{h}$ and a resultant lower $\Delta \mathrm{P}$ and assumed lower SSI, a gypsum evaporitive facies $(\mathrm{G})$ prevailed in the DS basin. In times of higher $\Delta \mathrm{h}, \Delta \mathrm{P}$ and $\mathrm{SSI}$, the halite evaporite facies $(\mathrm{H})$ prevailed. Similarly, regarding the process of density driven brine flow (DDBF) from the DS westward, the same relationship is encountered. Higher $\Delta \mathrm{h}$ and as a result higher $\triangle \mathrm{P}$ enlarges the DDBF, which by itself helps in the lowering of the DS level. As expected, the assumed DDBF is smaller in the case a brine depositing gypsum and larger in that of the more concentrated brine that deposits halite.

\section{Acknowledgments}

Nili Almog from the Geological Survey of Israel is acknowledged for drafting the figures.

\section{References}

Bar-Matthews, M., \& Ayalon A. (2003). Climatic conditions in the eastern Mediterranean during the last Glacial (60-10 ky) and their relations to the upper Palaeolithic in the Levant as inferred from oxygen and carbon systematics of cave deposits, In: Gorring-Morris N, Belfer-Cohen A (Eds.) More than Meets the Eye. Studies on Upper Paleolithic Diversity in the Near East, 13-18.

Bartov, Y., Agnon, A., Enzel, Y., \& Stein, M. (2006). Late Quaternary faulting and subsidence in the central Dead Sea basin. Israel Journal of Earth Sciences, 55, 17-31. http://dx.doi.org/10.1560/K74U-0772-1642-6282

Bartov, Y., Goldstein, S. L., Stein, M., \& Enzel, Y. (2003). Catastrophic arid episodes in the Eastern Mediterranean linked with the North Atlantic Heinrich events. Geology, 31, 439-442. http://dx.doi.org/10.1130/0091-7613(2003)031<0439:CAEITE>2.0.CO;2

Diersch, H. J. (2005).Finite Element Subsurface Flow and Transport Simulation System.User's Manual. FEFLOW Version 5.2. WASY GmbH. Berlin.

Enzel, Y., Bookman, R., Sharon, D., Gvirtzman, H., Dayan, U., Ziv, B., \& Stein, M. (2003). Late Holocene climates of the Near East deduced from Dead Sea level variations and modern regional winter rainfall. Quaternary Research, 60, 263-273.

http://dx.doi.org/10.1016/j.yqres.2003.07.011 
Garfunkel, Z. (1981). Internal structure of the Dead Sea Leaky Transform (rift) in relation to plate kinematics. Tectonophysics, 80, 81-108.

http://dx.doi.org/10.1016/0040-1951(81)90143-8

Grabe, A., Rodriger, T., Rink, K., Fischer, T., Sun, F., Wang, W., Siebert, C., \& Kolditz, O. (2013). Numerical analysis of the groundwater regime in the western Dead Sea escarpment, Israel+West Bank. Environmental Earth Sciences, 69, 571-585.

http://dx.doi.org/10.1007/s12665-012-1795-8

Horowitz, A. (2001).The Jordan Rift Valley. Balkema, Lisse, the Netherlands.730p.

http://dx.doi.org/10.1201/9781439834244

Kafri, U. (1984). Current subsurface seawater intrusion to base levels below sea level. Environmental and Geological Water Sciences, 6, 223-227.

http://dx.doi.org/10.1007/BF02509930

Kafri, U., \& Arad, A. (1979).Current subsurface intrusion of Mediterranean seawater. A possible source of groundwater salinity in the Rift Valley system, Israel. Journal of Hydrology, 44, 267-287. http://dx.doi.org/10.1016/0022-1694(79)90135-5

Kafri, U., \& Ecker, A. (1964). Neogene and Quaternary subsurface geology and hydrogeology of the Zevulun Plain. Israel Geological Survey Bulletin, 37, 1-13.

Kafri, U., \& Yechieli, Y. (2010). The role of hydrological base level in the formation of sub-horizontal caves horizons, example from the Dead Sea Basin, Israel. Environmental Earth Sciences, 61, 1145-1152. http://dx.doi.org/10.1007/s12665-009-0435-4

Kafri, U., Goldman, M., Levi, E., \& Wollman, S.(2014). Detection of saline groundwater bodies between the Dead Sea and the Mediterranean Sea, Israel, using the TDEM method and hydrochemical parameters. Environmental Processes, 1, 21-41.

http://dx.doi.org/10.1007/s40710-014-0001-2

Kafri, U., Goldman, M., Lyakhovsky, V., Scholl, C., Helwig, S., \& Tezkan, B. (2007). The configuration of the fresh-saline groundwater interface within the regional Judea Group carbonate aquifer in northern Israel between the Mediterranean and the Dead Sea base levels as delineated by deep geoelectromagnetic soundings. Journal of Hydrology, 344,123-134. http://dx.doi.org/10.1016/j.jhydrol.2007.07.003

Kafri, U., Shalev, E., Lyakhovsky, V., Wollman, S., \& Yechieli, Y. (2013).Numerical modeling of seawater intrusion into endorheic hydrological systems. Hydrogeology Journal, http://dx.doi.org/10.1007/s10040-013-0972-5

Katz, A., \& Starinsky, A. (2015). No draw down and no hyperaridity in the ancient Dead Sea (Comments to Torfstein's et al. (2015) paper, EPSL 412, 235-244). Earth and PlanetaryScience Letters, 427,303-305. http://dx.doi.org/10.1016/j.eps1.2015.07.006

Katz, A., Kolodny, Y., \& Nissenbaum, A. (1977). The geochemical evolution of the Pleistocene Lake Lisan-Dead Sea system. Geochimica et Cosmochimica Acta, 41, 1609-1626. http://dx.doi.org/10.1016/0016-7037(77)90172-7 
Neugebauer, I., Brauer, A., Schwab, M. J., Waldmann, N. D., Enzel, Y., ... Stein, M. (2014). Lithologyof the long sediment record recovered by the ICDP Dead Sea Deep Drilling Project (DSDDP). Quaternary Science Review, 102,149-165.

http://dx.doi.org/10.1016/j.quascirev.2014.08.013

Stanislavsky, E., \& Gvirtzman, H. (1999). Basin-scale migration of continental-rift brines: Paleohydrologic modeling of the Dead Sea basin. Geology, 27, 791-794.

http://dx.doi.org/10.1130/0091-7613(1999)027<0791:BSMOCR>2.3.CO;2

Starinsky, A. (1974). Relationship between Ca- chloride brines and sedimentary rocks in Israel. PhD thesis,Hebrew University Jerusalem (In Hebrew).

Stein, M. (2001). The sedimentary and geochemical record of Neogene-Quaternary water bodies in the Dead Sea basin- Inferences for the regional paleoclimatic history. Journal of Paleolimnology, 26, 271-282. http://dx.doi.org/10.1023/A:1017529228186

Torfstein, A., Goldstein, S. L., Kushnir, Y., Enzel, Y., Haug, G., \& Stein, M. (2015a).Dead Sea drawdown and monsoonal impacts in the Levant during the last interglacial. Earth and Planetary Science Letters, 412, 235-244. http://dx.doi.org/10.1016/j.eps1.2014.12.013

Torfstein, A., Goldstein, S. L., Kushnir, Y., Enzel, Y., Haug, G., \& Stein, M. (2015b). Response to comments on: Dead Sea drawdown and monsoonal impacts in the Levant during the last interglacial. Earth and Planetary Science Letters, 427,306-308.

http://dx.doi.org/10.1016/j.eps1.2015.07.014

Torfstein, A., Goldstein, S. L., Stein, M., \& Enzel, Y. (2013). Impacts of abrupt climate changes in the Levant from Last Glacial Dead Sea levels. Quaternary Science Review, 69, 1-7. http://dx.doi.org/10.1016/j.quascirev.2013.02.015

Torfstein, A., Haase-Schramm, A., Waldmann, M., Kolodny, Y., \& Stein, M. ( 2009). U-series and oxygen isotope chronology of the mid-Pleistocene Lake Amora (Dead Sea basin). Geochimica et Cosmochimica Acta, 73, 2603-2630.

http://dx.doi.org/10.1016/j.gca.2009.02.010

Waldmann, N., Stein, M., Ariztegui, D., \& Starinsky, A. (2009). Stratigraphy, depositional environments and level reconstruction of the last interglacial Lake Samra in the Dead Sea basin. Quaternary Research, 72, 1-15. http://dx.doi.org/10.1016/j.yqres.2009.03.005

Yechieli, Y., Kafri, U., Wollman, S., Shalev, E., \& Lyakhovsky, V. (2009). The effect of base level changes and geological structures on the location of the groundwater divide, as exhibited in the hydrological system between the Dead Sea and the Mediterranean Sea. Journal of Hydrology, 378, 218-229. http://dx.doi.org/10.1016/j.jhydrol.2009.09.023

Zak, I. (1967).The geology of Mount Sedom. PhD thesis,Hebrew University Jerusalem (In Hebrew). 


\section{Macrothink \\ Environmental Management and Sustainable Development \\ ISSN 2164-7682}

\section{Copyright Disclaimer}

Copyright for this article is retained by the author(s), with first publication rights granted to the journal.

This is an open-access article distributed under the terms and conditions of the Creative Commons Attribution license (http://creativecommons.org/licenses/by/3.0/). 